\title{
GIS-based assessment of landslide susceptibility using certainty factor and index of entropy models for the Qianyang County of Baoji city, China
}

\author{
Qiqing Wang ${ }^{1}$, Wenping Li ${ }^{1, *}$, Wei Chen $^{2}$ and Hanying Bai ${ }^{1}$ \\ ${ }^{1}$ School of Resources and Earth Science, China University of Mining and Technology, Xuzhou 221116, China. \\ ${ }^{2}$ School of Geology and Environment, Xi'an University of Science and Technology, Xi'an 710054, China. \\ ${ }^{*}$ Corresponding author.e-mail: wpligroup@126.com
}

The main goal of this study is to produce landslide susceptibility maps for the Qianyang County of Baoji city, China, using both certainty factor $(\mathrm{CF})$ and index of entropy (IOE) models. At first, a landslide inventory map was prepared using earlier reports and aerial photographs as well as by carrying out field surveys. A total of 81 landslide locations were detected. Out of these, 56 (70\%) landslides were randomly selected as training data for building landslide susceptibility models and the remaining $25(30 \%)$ were used for the validation purposes. Then, a total number of 15 landslide causative factors, such as slope angle, slope aspect, general curvature, plan curvature, profile curvature, altitude, distance to faults, distance to rivers, distance to roads, the sediment transport index (STI), the stream power index (SPI), the topographic wetness index (TWI), geomorphology, lithology, and rainfall, were used in the analysis. The susceptibility maps produced using CF and IOE models had five different susceptibility classes such as very low, low, moderate, high, and very high. Finally, the output maps were validated using the validation data (i.e., 30\% landslide location data that was not used during the model construction), using the area under the curve (AUC) method. The 'success rate' curve showed that the area under the curve for CF and IOE models were $0.8433(84.33 \%)$ and $0.8227(82.27 \%)$ accuracy, respectively. Similarly, the validation result showed that the susceptibility map using CF model has the higher prediction accuracy of $82.32 \%$, while for IOE model it was $80.88 \%$. The results of this study showed that the two landslide susceptibility maps obtained were successful and can be used for preliminary land use planning and hazard mitigation purpose.

\section{Introduction}

Landslides, responsible for considerable loss of property and lives every year, are dangerous natural hazards. In many countries, the annual loss of lives and property due to landslides are greater than any other natural disasters, including earthquakes, floods, and windstorms. Globally, landslides cause thousands of deaths and injuries each year and property damage of about billions of dollars (Lee and Pradhan 2007; Solaimani et al. 2013). In China, more than 10,000 hazardous landslides occurred in 2014, which caused deaths and injuries to a total number of 618 people and a direct economic loss of 5.41 billion CNY (http://www. cigem.gov.cn). In addition, currently tens of millions of people still live under the high-risk threat of landslides (Liu et al. 2013).

The main goal of landslide susceptibility analysis is to identify dangerous and high risk areas

Keywords. Landslide; susceptibility mapping; certainty factor (CF); index of entropy (IOE). 
and thus landslide damage can be reduced through suitable mitigation measures (Kannan et al. 2013; Solaimani et al. 2013). Over the decades, number of approaches have been proposed to assess landslide susceptibility based on geographic information systems (GIS) using different models. Many of these studies have applied probabilistic models such as frequency ratio (FR), weight of evidence (WOE), etc. (Akgun et al. 2008; Vijith and Madhu 2008; Oh et al. 2009; Yilmaz and Keskin 2009; Youssef et al. 2009, 2012; Pradhan and Youssef 2010; Pradhan et al. 2011; Akgun et al 2012; Neuhäuser et al. 2012; Saponaro et al. 2014; Sujatha et al. 2014). Statistical models such as logistic regression (Akgun 2012; Devkota et al. 2013; Grozavu et al. 2013; Ozdemir and Altural 2013; Solaimani et al. 2013), bivariate (Bednarik et al. 2010; Pareek et al. 2010; Pradhan and Lee 2010; Pradhan and Youssef 2010; Pourghasemi et al. 2013a) and multivariate (Pradhan 2010a, b; Choi et al. 2012) have been used in landslide susceptibility mapping. Other different methods such as spatial multicriteria decision analysis (MCDA) approach (Akgun and Turk 2010; Akgun 2012), analytical hierarchy process (AHP) (Yalcin et al. 2011; Pourghasemi et al. 2012a; Park et al. 2013), certainty factor (CF) model (Devkota et al. 2013; Pourghasemi et al. 2013c), artificial neural network model (Chauhan et al. 2010; Pouydal et al. 2010; Pradhan and Buchroithner 2010; Park et al. 2013), index of entropy (IOE) model (Mihaela et al. 2011; Devkota et al. 2013), decision-tree methods (Nefeslioglu et al. 2010; Pradhan 2013), fuzzy logic (Pourghasemi et al. 2012a, 2012b, 2012c; Guettouche 2013; Sharma et al. 2013), support vector machine (SVM) (Yilmaz 2010; Pradhan 2013) and neuro-fuzzy (Vahidnia et al. 2010; Sezer et al. 2011) have also been employed for the purpose of landslide susceptibility mapping. Nevertheless, few studies have so far been carried out on landslide susceptibility analysis in this area. The main difference between the present study and the approaches described in the aforementioned literature is that certainty factor and index of entropy models were applied and compared for landslide susceptibility mapping in this study area.

This study aims to apply both certainty factor (CF) and index of entropy (IOE) models to develop reliable landslide susceptibility maps of the Qianyang County of Baoji, China and to find a better model that is more accurate in landslide susceptibility mapping in the study area. In order to achieve this, both certainty factor and index of entropy analysis methodology, to obtain landslide susceptibility maps using the geographic information system were developed, applied, and verified in the study area.

\section{Study area}

Geographically, the study area is located in centralwestern part of China, and lies between latitudes $34^{\circ} 34^{\prime} 34^{\prime \prime}-34^{\circ} 56^{\prime} 56^{\prime \prime} \mathrm{N}$ and longitudes $106^{\circ} 56^{\prime} 15^{\prime \prime}-$ $107^{\circ} 22^{\prime} 31^{\prime \prime} \mathrm{E}$ (figure 1). The study area covers roughly a surface area of $996.46 \mathrm{~km}^{2}$ and belongs to the Qianyang County of Baoji city, China. The temperature of the area varies between $-20.6^{\circ} \mathrm{C}$ in winter and $40.5^{\circ} \mathrm{C}$ in summer, with an yearly average of $11.8^{\circ} \mathrm{C}$. The mean annual rainfall according to local weather station in a period of 40 years is around $627.4 \mathrm{~mm}$, and the maximum rainfall appears in August (C.H. of China Meteorological Administration (CMA), 2014). Main streams in the study area are the Wei and Jing Rivers. The landform of the area can be classified into mountain, hill, and plain, which result in large elevation difference. On the whole, the northern regions are relatively higher with the highest elevation $1560 \mathrm{~m}$, and the southern regions are relatively lower with the lowest elevation $752 \mathrm{~m}$. The slope angle values vary between $0^{\circ}$ and $38^{\circ}$. The main commercial agricultural products in the region are wheat and Sorghum. Apart from the agricultural areas, the other mainland cover types are pasture and forest. In this area, the traffic is convenient. Up to now, the County road mileage is about $389.8 \mathrm{~km}$. The population of the County was about 132,000 in the year 2010. There is a wide gap in the population density between a plain terrain and a mountainous area. The average density of population in plain terrain is approximately 163 people per square kilometer, while in mountainous area it is about 28 people per square kilometer. Major settlements are shown in figure 1 (Yang 2009). The area is mainly distributed by loess. In total, 81 landslides were mapped in the study area.

\section{Data preparation}

\subsection{Landslide inventory map}

The landslide inventory map, providing information for the assessment of the influence of different causative factors on landslide occurrence, is the backbone of landslide susceptibility studies (Van Westen et al. 2006; Youssef et al. 2014a, b). The reliability and accuracy of the collected data related to landslides affect the success of landslide susceptibility analysis. Landslide inventory maps can be prepared either by collecting the information related with landslides or by analyzing satellite imagery and aerial photographs coupled with field surveys using GPS (Pradhan and Kim 2014). In order to produce a detailed and reliable 


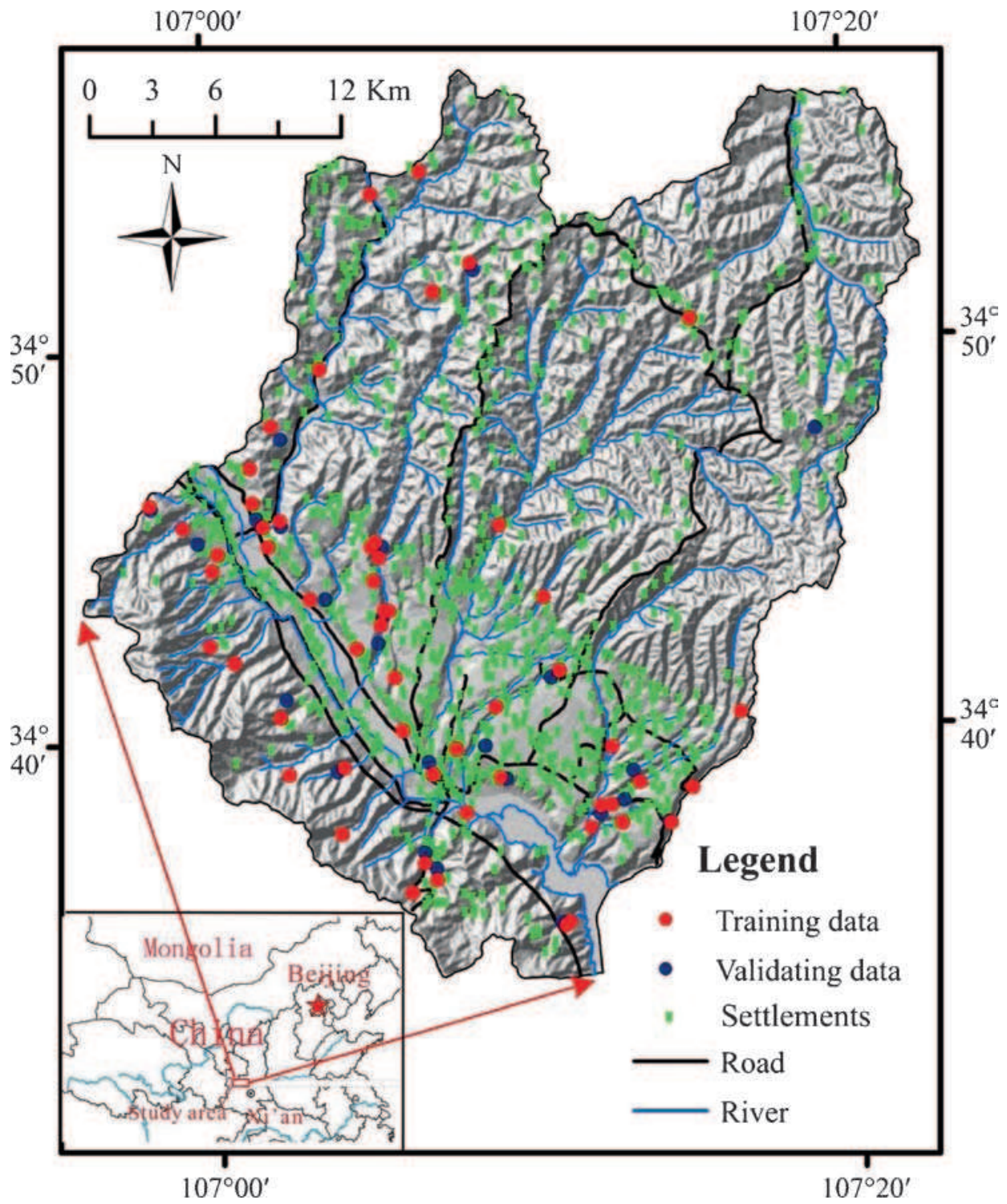

Figure 1. Location of the study area.

landslide inventory map, extensive field surveys and observations were performed during 2009 in the study area. A total number of 81 landslides were identified and mapped by evaluating aerial photos in 1:50,000 scale, with well supported field surveys and subsequently digitized for further analysis. The locations (centroid) of 81 landslides are mapped in figure 1. From these landslides, randomly $56(70 \%)$ locations were chosen for the preparation of landslide susceptibility maps, while the remaining $25(30 \%)$ cases were used for testing the model.

\subsection{Thematic layers}

In order to apply certainty factor and index of entropy models, a spatial database that considers 15 factors, including slope angle, slope aspect, general curvature, plan curvature, profile curvature, altitude, distance to faults, distance to rivers, distance to roads, STI, SPI, TWI, geomorphology, lithology and rainfall, was designed and constructed. Data of these factors, such as slope angle, slope aspect, general curvature, plan curvature, profile curvature, altitude, STI, SPI, TWI, were mainly produced from the DEM. Other parameters were mainly collected from available resources (geological structure map, environment geology map, road map and drainage map, etc.). All of these data were produced in raster format with a pixel size of $30 \times$ $30 \mathrm{~m}^{2}$ to be compatible with the spatial resolution. A brief description of each data layer preparation is given here.

Slope degree, with direct effect on landslide formation, is a very important parameter in the slope stability analysis, and it is frequently used in preparing landslide susceptibility maps (Lee and Min 2001; Saha et al. 2005; Gorsevski et al. 2012). Slope configuration and steepness play 

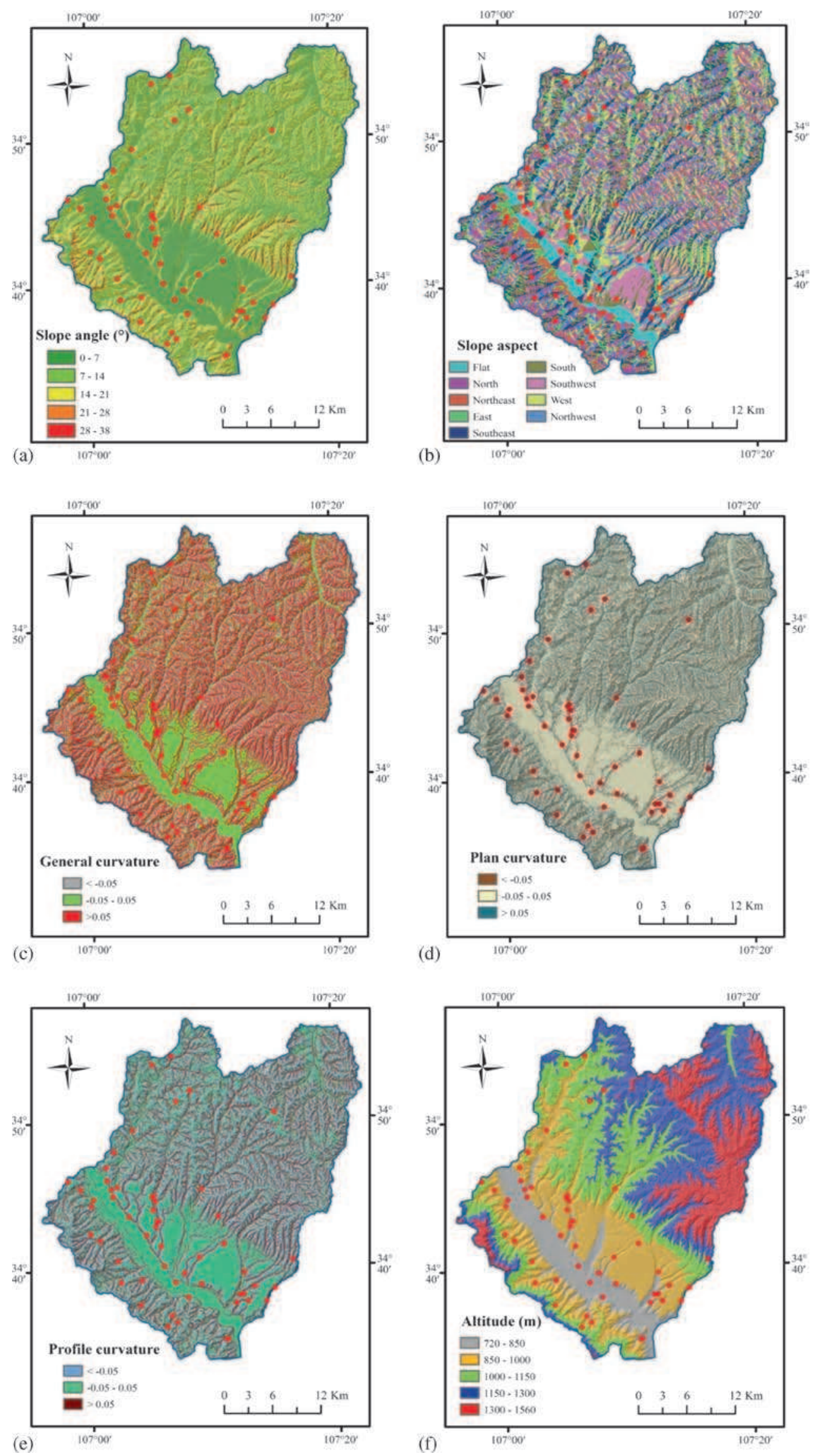

Figure 2(a-f). (a) Slope angle map, (b) slope aspect map, (c) general curvature map, (d) plan curvature map, (e) profile curvature map, and (f) altitude map of the study area. 

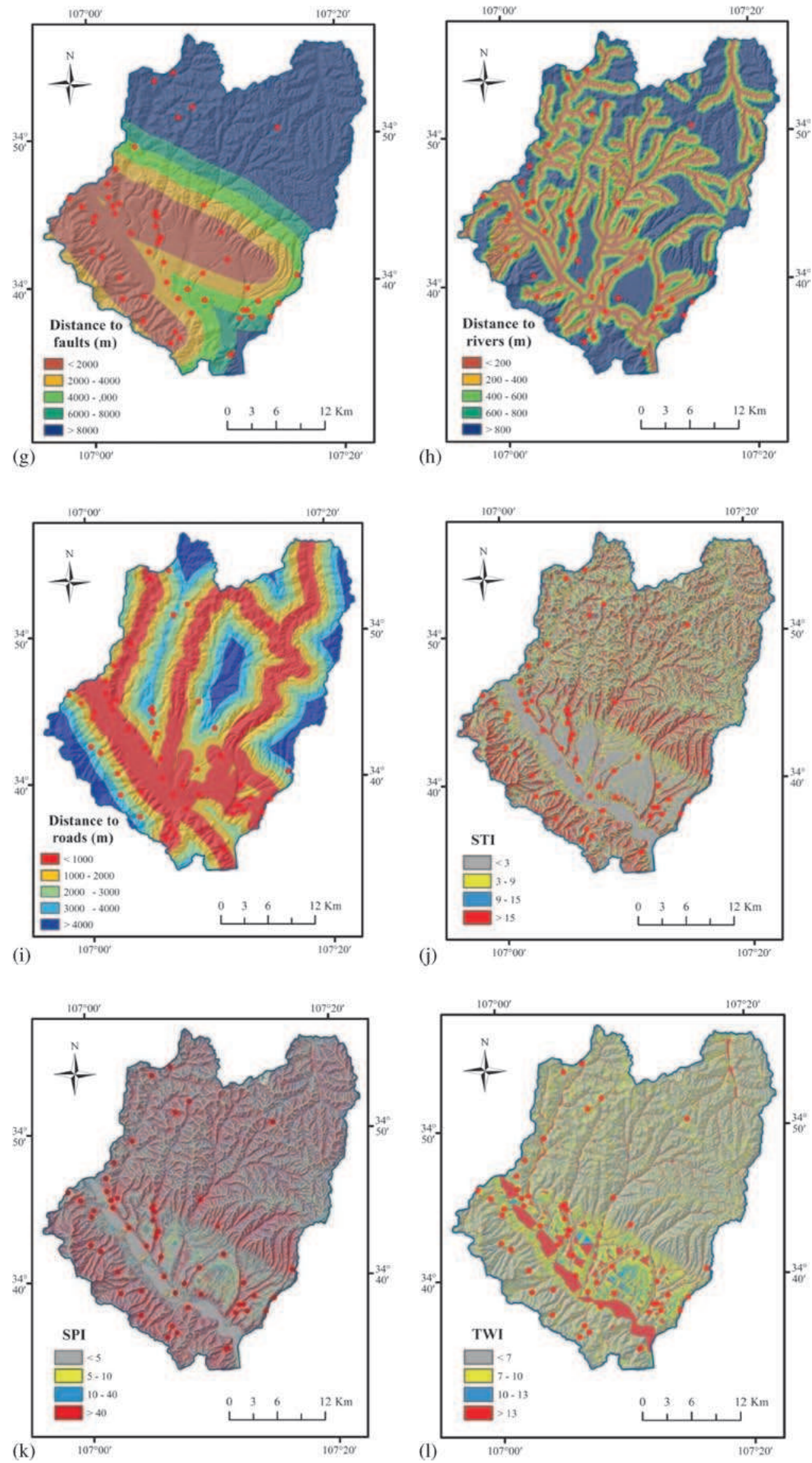

Figure 2(g-i). (g) Distance to faults map, (h) distance to rivers map, (i) distance to roads map, (j) STI map, (k) SPI map, and (l) TWI map of the study area. 

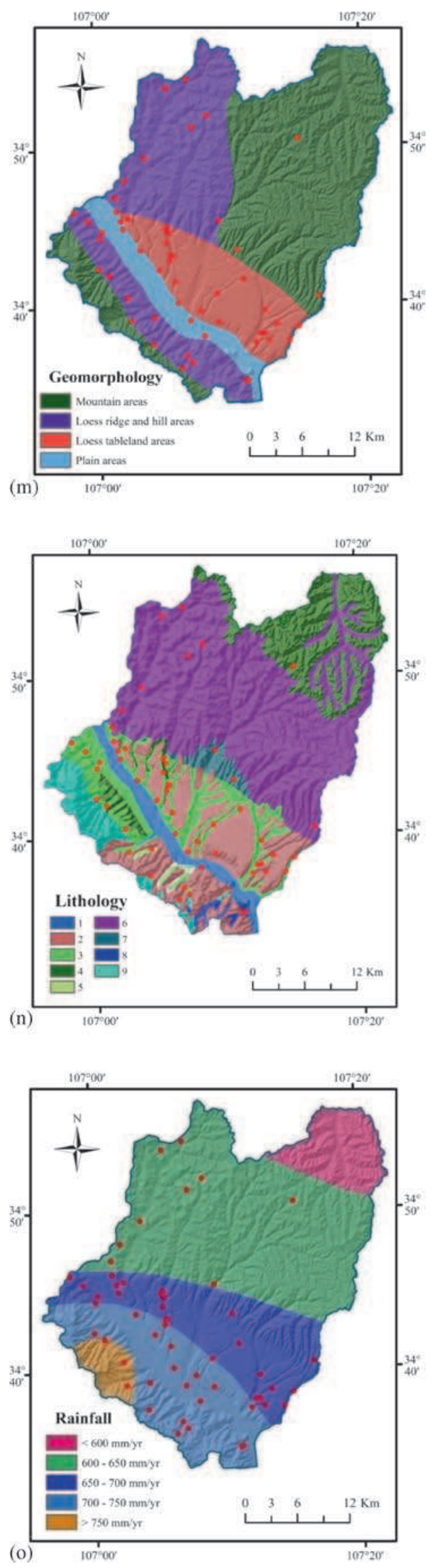

Figure 2(m-o). (m) Geomorphology map, (n) lithology map, and (o) rainfall map of the study area.

an important role in conjunction with lithology (Pourghasemi et al. 2012c). In this study, the slope degree map was prepared from the $30 \times 30 \mathrm{~m}^{2}$ digital elevation model (DEM) collected from the advanced space-borne thermal emission and reflection radiometer (ASTER) using ArcGIS 10.0 (ESRI Inc., Redlands, CA, USA) and was classified into five classes considering the steepness of the terrain (Kayastha et al. 2013; Liu et al. 2014), i.e., $0-7^{\circ}, 7^{\circ}-14^{\circ}, 14^{\circ}-21^{\circ}, 21^{\circ}-28^{\circ}$, and $28^{\circ}-38^{\circ}$ (figure 2a). ArcGIS 10.0 analysis was performed to discover in which slope group the landslide happened and the rate of occurrence was also observed. The landslide percentage in each slope group class is determined as a percentage of slopes. The result indicates that about $94.6 \%$ of the landslides occurred on slopes ranging from $0^{\circ}$ to $21^{\circ}$ (table 2).

Slope aspect describes the direction of slope. The slope aspect controls the formation of the landslide such as lineaments, rainfalls, wind effects, and exposure to sunshine (Yalcin and Bulut 2007; Pourghasemi et al. 2012a). In this study, the slope aspect map of the study area was produced to show the relationship between aspect and landslide. Aspect regions were divided into nine directional classes as flat $(-1)$, north $\left(337.5^{\circ}-360^{\circ}, 0^{\circ}\right.$ $\left.-22.5^{\circ}\right)$, northeast $\left(22.5^{\circ}-67.5^{\circ}\right)$, east $\left(67.5^{\circ}-112.5^{\circ}\right)$, southeast $\left(112.5^{\circ}-157.5^{\circ}\right)$, south $\left(157.5^{\circ}-202.5^{\circ}\right)$, southwest $\left(202.5^{\circ}-247.5^{\circ}\right)$, west $\left(247.5^{\circ}-292.5^{\circ}\right)$, and northwest $\left(292.5^{\circ}-337.5^{\circ}\right)$ (figure $2 \mathrm{~b}$ ).

Commonly, general curvature, defined as the rate of change of slope degree or aspect, has been argued to affect slope stability. The characterization of slope morphology and flow can be analyzed with the help of the general curvature map (Nefeslioglu et al. 2008). Plan curvature is described as the curvature of a contour line formed by intersection of a horizontal plane with the surface. It influences the convergence and divergence of flow across a surface. The profile curvature, the vertical plane parallel to the slope direction, affects the acceleration and deceleration of downslope flows and, as a result, influences erosion and deposition (Kannan et al. 2013; Kritikos and Davies 2014). In this study, the general curvature, plan curvature and profile curvature were derived from the DEM in ArcGIS 10.0, and they were divided into three classes: $<-0.05$, 0.05 to 0.05 , and $>0.05$, respectively (figure $2 \mathrm{c}-\mathrm{e}$ ).

Altitude is another frequently conditioning factor for landslide susceptibility analysis because it is controlled by several geologic and geomorphological processes (Gorsevski et al. 2012; Pourghasemi et al. 2012b; Pradhan and Kim 2014). Landslides usually occur at intermediate elevations since slopes tend to be covered by a layer of thin colluvium that is prone to landslides (Dai and Lee 2002; Dragićević et al. 2015). In the study area, the elevation of the study area ranged from 720 to $1560 \mathrm{~m}$, 
and five categories of elevations were identified, i.e., 720-850, 850-1000, 1000-1150, 1150-1300, and 1300-1560 m (figure 2f).

Geological fault, responsible for triggering a large number of landslides due to the tectonic breaks that usually decrease the rock strength, was also a necessary parameter in the susceptibility analysis. In study area, five different buffer zones of the distance to faults were prepared from geological maps using the Euclidean distance interpolation method (figure $2 \mathrm{~g}$ ).

Distance to rivers, an important parameter controlling the stability of a slope, is the saturation degree of the material on the slope. The closeness of the slope to drainage structures is another important factor for landslide susceptibility analysis (Pourghasemi et al. 2012b; Park et al. 2013). To determine the degree to which the streams affected the slopes, five different buffer categories were created using Euclidean distance interpolation method (figure $2 \mathrm{~h}$ ).

Similar to the distance of slopes to rivers, the distance to roads has been considered as one of the most important anthropogenic factors influencing landslide occurrences that can be the cause of cut slope creations through construction of roads that disturbs the natural topography and affects the stability of the slope (Pourghasemi et al. 2012b; Demir et al. 2013). The distance to roads was calculated by Euclidean distance tool of the GIS application and it reclassified the resultant map into five classes: 0-1000, 1000-2000, 2000-3000, 3000-4000, and $>4000 \mathrm{~m}$ (figure $2 \mathrm{i}$ ).

The sediment transport index (STI), reflecting the erosive power of the overland flow, was derived by considering the transport capacity limiting sediment flux and catchment evolution erosion theories (Devkota et al. 2013; Pradhan and Kim 2014). In this study, STI was divided into four classes $<3,3-9,9-15$, and $>15$ (figure $2 \mathrm{j}$ ).
The stream power index (SPI), a measure of the erosion power of the stream, is also considered as a factor contributing towards stability within the study area (Conforti et al. 2011; Regmi et al. 2014). The SPI is expressed as SPI $=A_{S} \times \tan (\beta)$, where $A_{S}$ is the specific catchment's area and $\beta$ is the local slope gradient measured in degrees (Moore et al. 1988; Park et al. 2013). The SPI map of the study area was classified into four classes: $<5,5-10,10-40$, and $>40$ (figure $2 \mathrm{k}$ ).

The topographic wetness index (TWI) describes the effect of topography on the location and size of saturated source areas of runoff generation, and it is another topographic factor within the runoff model (Pourghasemi et al. 2013b; Pradhan and Kim 2014). TWI is calculated as: $\operatorname{Ln}\left[A_{S} / \tan (\beta)\right]$, where $A_{S}$ is the specific catchment area of each cell and $\beta$ represents the slope gradient (in degrees) of the topographic heights (Moore et al. 1988; Saadatkhah et al. 2014). In the present study, the TWI values were arranged in four classes: $<7,7-10$, $10-13$, and $>13$ (figure 21 ).

Geomorphology is considered as an important factor closely related to landslide occurrence. The detailed geomorphology map, derived from the geological maps with limited field check (Kannan et al. 2013), consists of five prominent units such as mountain areas, loess ridge and hill areas, loess tableland areas and plain areas (figure $2 \mathrm{~m}$ ).

Lithology is one of the most common determinant factors in landslide stability studies because different lithological units have different landslide susceptibility values, which can provide important information regarding landslide susceptibility of a region (Yalcin and Bulut 2007; Pourghasemi et al. 2012a). In this study, the lithology map of the study area is compiled from existing geological maps $(1 / 100,000$ scale) in ArcGIS 10.0. The study area is covered with various types of lithological units. Their names, lithologic

Table 1. Description of geological units of the study area (Wang 2008).

\begin{tabular}{|c|c|c|c|c|}
\hline No. & Code & Formation & Lithology & Geological age \\
\hline 1 & $\mathrm{Q}_{4}$ & - & Sand, gravel, silty clay & Quaternary \\
\hline 2 & $\mathrm{Q}_{3}$ & - & Loess & Quaternary \\
\hline 3 & $\mathrm{Q}_{2}$ & - & Loess & Quaternary \\
\hline 4 & $\mathrm{Q}_{1}$ & - & Loess & Quaternary \\
\hline 5 & $\mathrm{~N}_{2}$ & - & Glutenite, sandstone, siltstone & Neogene \\
\hline \multirow[t]{4}{*}{6} & $\mathrm{~K}_{1 \mathrm{Lh}}$ & Luohandong & Sandstone, siltstone, mudstone & Early Cretaceous \\
\hline & $\mathrm{K}_{1 \mathrm{~h}}$ & Huanhehuachi & Sandstone, siltstone, mudstone & Early Cretaceous \\
\hline & $\mathrm{K}_{1 \mathrm{~L}}$ & Luohe & Glutenite, sandstone & Early Cretaceous \\
\hline & $\mathrm{K}_{1 \mathrm{y}}$ & Yijun & Glutenite & Early Cretaceous \\
\hline \multirow[t]{2}{*}{7} & $\mathrm{~J}_{3 \mathrm{f}}$ & Fenfanghe & Glutenite, sandstone, siltstone & Late Jurassic \\
\hline & $\mathrm{J}_{2 \mathrm{z}}$ & Zhiluo & Glutenite, siltstone, shale & Middle Jurassic \\
\hline 8 & $\mathrm{P}_{1}$ & - & Sandstone, shale & Early Permian \\
\hline 9 & $\mathrm{O}_{1-2}$ & - & Limestone, dolomite & Early-Middle Ordovician \\
\hline
\end{tabular}


Table 2. Spatial relationship between each landslide conditioning factor and landslide by CF and IOE models.

\begin{tabular}{|c|c|c|c|c|c|c|c|c|c|c|}
\hline Factors & Classes & $\begin{array}{l}\text { Percentage of } \\
\text { landslide }(\%)\end{array}$ & $\begin{array}{l}\text { Percentage of } \\
\text { domain }(\%)\end{array}$ & $\mathrm{CF}$ & $P_{i j}$ & $\left(P_{i j}\right)$ & $H_{j}$ & $H_{\mathrm{jmax}}$ & $I_{j}$ & $W_{j}$ \\
\hline \multirow[t]{5}{*}{ Slope angle $\left({ }^{\circ}\right)$} & $0-7$ & 30.36 & 32.51 & -0.07 & 0.93 & 0.23 & 2 & 2.32 & 0.14 & 0.11 \\
\hline & $7-14$ & 33.93 & 35.59 & -0.05 & 0.95 & 0.24 & & & & \\
\hline & $14-21$ & 30.36 & 26.18 & 0.14 & 1.16 & 0.29 & & & & \\
\hline & $21-28$ & 5.36 & 5.42 & -0.01 & 0.99 & 0.25 & & & & \\
\hline & $28-38$ & 0.00 & 0.30 & -1.00 & 0.00 & 0.00 & & & & \\
\hline \multirow[t]{9}{*}{ Slope aspect } & Flat & 0.00 & 6.16 & -1.00 & 0.00 & 0.00 & 2.9 & 3.17 & 0.09 & 0.08 \\
\hline & North & 16.07 & 9.62 & 0.40 & 1.67 & 0.19 & & & & \\
\hline & Northeast & 12.50 & 10.23 & 0.18 & 1.22 & 0.14 & & & & \\
\hline & East & 14.29 & 11.21 & 0.22 & 1.27 & 0.15 & & & & \\
\hline & Southeast & 10.71 & 13.37 & -0.20 & 0.80 & 0.09 & & & & \\
\hline & South & 7.14 & 9.77 & -0.27 & 0.73 & 0.08 & & & & \\
\hline & Southwest & 16.07 & 13.16 & 0.18 & 1.22 & 0.14 & & & & \\
\hline & West & 5.36 & 13.30 & -0.60 & 0.40 & 0.05 & & & & \\
\hline & Northwest & 17.86 & 13.19 & 0.26 & 1.35 & 0.16 & & & & \\
\hline \multirow[t]{3}{*}{ General curvature } & $<-0.05$ & 46.43 & 36.59 & 0.21 & 1.27 & 0.43 & 1.56 & 1.58 & 0.02 & 0.02 \\
\hline & $-0.05-0.05$ & 23.21 & 26.92 & -0.14 & 0.86 & 0.29 & & & & \\
\hline & $>0.05$ & 30.36 & 36.48 & -0.17 & 0.83 & 0.28 & & & & \\
\hline \multirow[t]{3}{*}{ Plan curvature } & $<-0.05$ & 28.57 & 27.19 & 0.05 & 1.05 & 0.36 & 1.56 & 1.58 & 0.02 & 0.02 \\
\hline & $-0.05-0.05$ & 50.00 & 43.00 & 0.14 & 1.16 & 0.40 & & & & \\
\hline & $>0.05$ & 21.43 & 29.81 & -0.28 & 0.72 & 0.25 & & & & \\
\hline \multirow[t]{3}{*}{ Profile curvature } & $<-0.05$ & 26.79 & 30.49 & -0.12 & 0.88 & 0.29 & 1.52 & 1.58 & 0.04 & 0.04 \\
\hline & $-0.05-0.05$ & 26.79 & 37.24 & -0.28 & 0.72 & 0.24 & & & & \\
\hline & $>0.05$ & 46.43 & 32.27 & 0.30 & 1.44 & 0.47 & & & & \\
\hline \multirow[t]{5}{*}{ Altitude (m) } & $720-850$ & 41.07 & 11.95 & 0.71 & 3.44 & 0.59 & 1.33 & 2.32 & 0.43 & 0.50 \\
\hline & $850-1000$ & 46.43 & 24.96 & 0.46 & 1.86 & 0.32 & & & & \\
\hline & $1000-1150$ & 7.14 & 22.91 & -0.69 & 0.31 & 0.05 & & & & \\
\hline & $1150-1300$ & 3.57 & 25.48 & -0.86 & 0.14 & 0.02 & & & & \\
\hline & $1300-1560$ & 1.79 & 14.69 & -0.88 & 0.12 & 0.02 & & & & \\
\hline \multirow[t]{5}{*}{ Distance to faults (m) } & $0-2000$ & 51.79 & 26.72 & 0.48 & 1.94 & 0.34 & 2.12 & 2.32 & 0.09 & 0.10 \\
\hline & $2000-4000$ & 16.07 & 14.09 & 0.12 & 1.14 & 0.20 & & & & \\
\hline & $4000-6000$ & 14.29 & 10.78 & 0.25 & 1.33 & 0.23 & & & & \\
\hline & $6000-8000$ & 8.93 & 7.89 & 0.12 & 1.13 & 0.20 & & & & \\
\hline & $>8000$ & 8.93 & 40.52 & -0.78 & 0.22 & 0.04 & & & & \\
\hline \multirow[t]{5}{*}{ Distance to rivers $(\mathrm{m})$} & $0-200$ & 46.43 & 22.26 & 0.52 & 2.09 & 0.43 & 2.12 & 2.32 & 0.09 & 0.08 \\
\hline & $200-400$ & 14.29 & 18.01 & -0.21 & 0.79 & 0.16 & & & & \\
\hline & $400-600$ & 8.93 & 14.14 & -0.37 & 0.63 & 0.13 & & & & \\
\hline & $600-800$ & 7.14 & 11.30 & -0.37 & 0.63 & 0.13 & & & & \\
\hline & $>800$ & 23.21 & 34.29 & -0.32 & 0.68 & 0.14 & & & & \\
\hline
\end{tabular}




\begin{tabular}{|c|c|c|c|c|c|c|c|c|c|c|}
\hline \multirow[t]{5}{*}{ Distance to roads $(\mathrm{m})$} & $0-1000$ & 53.57 & 36.73 & 0.31 & 1.46 & 0.35 & 1.91 & 2.32 & 0.18 & 0.15 \\
\hline & $1000-2000$ & 14.29 & 23.90 & -0.40 & 0.60 & 0.15 & & & & \\
\hline & $2000-3000$ & 23.21 & 17.75 & 0.24 & 1.31 & 0.32 & & & & \\
\hline & $3000-4000$ & 8.93 & 11.81 & -0.24 & 0.76 & 0.18 & & & & \\
\hline & $>4000$ & 0.00 & 9.81 & -1.00 & 0.00 & 0.00 & & & & \\
\hline \multirow[t]{4}{*}{ STI } & $<3$ & 12.50 & 24.60 & -0.49 & 0.51 & 0.13 & 1.9 & 2.00 & 0.05 & 0.05 \\
\hline & $3-9$ & 28.57 & 26.81 & 0.06 & 1.07 & 0.27 & & & & \\
\hline & $9-15$ & 16.07 & 19.98 & -0.20 & 0.80 & 0.21 & & & & \\
\hline & $>15$ & 42.86 & 28.60 & 0.33 & 1.50 & 0.39 & & & & \\
\hline \multirow[t]{4}{*}{ SPI } & $<5$ & 5.36 & 14.80 & -0.64 & 0.36 & 0.11 & 1.81 & 2.00 & 0.10 & 0.08 \\
\hline & $5-10$ & 5.36 & 10.85 & -0.51 & 0.49 & 0.15 & & & & \\
\hline & $10-40$ & 32.14 & 34.55 & -0.07 & 0.93 & 0.29 & & & & \\
\hline & $>40$ & 57.14 & 39.81 & 0.30 & 1.44 & 0.45 & & & & \\
\hline \multirow[t]{4}{*}{ TWI } & $<7$ & 55.36 & 55.01 & 0.01 & 1.01 & 0.23 & 1.93 & 2.00 & 0.04 & 0.04 \\
\hline & $7-10$ & 26.79 & 30.12 & -0.11 & 0.89 & 0.20 & & & & \\
\hline & $10-13$ & 10.71 & 6.28 & 0.41 & 1.71 & 0.38 & & & & \\
\hline & $>13$ & 7.14 & 8.59 & -0.17 & 0.83 & 0.19 & & & & \\
\hline \multirow[t]{4}{*}{ Geomorphology } & Mountain areas & 5.36 & 45.00 & -0.88 & 0.12 & 0.02 & 1.64 & 2.00 & 0.18 & 0.26 \\
\hline & Loess ridge and hill areas & 41.07 & 32.15 & 0.22 & 1.28 & 0.22 & & & & \\
\hline & Loess tableland areas & 39.29 & 15.59 & 0.60 & 2.52 & 0.43 & & & & \\
\hline & Plain areas & 14.29 & 7.26 & 0.49 & 1.97 & 0.33 & & & & \\
\hline \multirow[t]{9}{*}{ Lithology } & 1 & 3.57 & 4.41 & -0.19 & 0.81 & 0.05 & 2.66 & 3.17 & 0.16 & 0.31 \\
\hline & 2 & 30.36 & 17.11 & 0.44 & 1.77 & 0.10 & & & & \\
\hline & 3 & 39.29 & 10.99 & 0.72 & 3.58 & 0.21 & & & & \\
\hline & 4 & 3.57 & 14.29 & -0.75 & 0.25 & 0.01 & & & & \\
\hline & 5 & 1.79 & 0.31 & 0.82 & 5.68 & 0.33 & & & & \\
\hline & 6 & 12.50 & 45.68 & -0.73 & 0.27 & 0.02 & & & & \\
\hline & 7 & 3.57 & 2.13 & 0.40 & 1.68 & 0.10 & & & & \\
\hline & 8 & 1.79 & 0.71 & 0.60 & 2.51 & 0.14 & & & & \\
\hline & 9 & 3.57 & 4.37 & -0.18 & 0.82 & 0.05 & & & & \\
\hline \multirow[t]{5}{*}{ Rainfall } & $<600 \mathrm{~mm} / \mathrm{yr}$ & 0.00 & 8.27 & -1.00 & 0.00 & 0.00 & 1.80 & 2.32 & 0.22 & 0.27 \\
\hline & $600-650 \mathrm{~mm} / \mathrm{yr}$ & 16.07 & 45.99 & -0.65 & 0.35 & 0.06 & & & & \\
\hline & $650-700 \mathrm{~mm} / \mathrm{yr}$ & 42.86 & 20.99 & 0.51 & 2.04 & 0.34 & & & & \\
\hline & $700-750 \mathrm{~mm} / \mathrm{yr}$ & 33.93 & 21.25 & 0.37 & 1.60 & 0.26 & & & & \\
\hline & $>750 \mathrm{~mm} / \mathrm{yr}$ & 7.14 & 3.50 & 0.51 & 2.04 & 0.34 & & & & \\
\hline
\end{tabular}


characteristics, and ages of the geological units are provided in table 1 , and the general geological setting of the area is shown on the source map (figure 2n).

The rainfall was taken into account as a triggering factor for landslide initiation, thus it is another one of the main parameters in landslide susceptibility mapping. For this study, the annual rainfall map was produced, using the data of the weather stations of eight towns in the area and applying the inverse distance weighted (IDW) interpolation method. This map was reclassified into five classes: $<600,600-650,650-700,700-750$, and $>750 \mathrm{~mm} / \mathrm{yr}$ (figure 2o).

\section{Modelling approach}

\subsection{Certainty factor model}

Certainty factor approach, one of the proposed favorability functions to deal with the problem of combination of heterogeneous data, has been widely used for mapping landslide susceptibility (Kanungo et al. 2011; Sujatha et al. 2012; Pourghasemi et al. 2013c; Liu et al. 2014). The function of probability (certainty factor) was proposed by Shortliffe and Buchanan (1975) in the beginning, and later improved by Heckeman (1986), and the expression is as:

$C F= \begin{cases}\left(P P_{a}-P P_{s}\right) /\left(P P_{a}\left(1-P P_{s}\right)\right) & \text { if } P P_{a} \geq P P_{s} \\ \left(P P_{a}-P P_{s}\right) /\left(P P_{s}\left(1-P P_{a}\right)\right) & \text { if } P P_{a}<P P_{s}\end{cases}$

where $P P_{a}$ is the conditional probability of landslide event occurring in category $a . P P_{s}$ is the prior probability of total number of landslide events in the study area $a$. The certainty factor ranges between -1 and 1 ; positive values means an increasing certainty in landslide occurrence, and negative values correspond to a decreasing certainty in landslide occurrence. A value close to zero means that there is not enough information about the variable and thus, it is difficult to give any indication about the certainty of the landslide occurrence (Sujatha et al. 2012; Dou et al. 2014).

The CF values of all the thematic layers used in the present study were calculated in ArcGIS 10.0 and Microsoft Excel based on equation (1), and the result is given in table 2 . Then, the CF values of the causative factor were pair-wise based upon the combination rule given in the following equation (Pourghasemi et al. 2013c; Dou et al. 2014; Ilia et al. 2015):

$$
Z= \begin{cases}X+Y-X Y & X, Y \geq 0 \\ (X+Y) /(1-\min (|X|,|Y|)) & X * Y<0 \\ X+Y+X Y & X, Y<0\end{cases}
$$

By using the integration rule of equation (2), the pair-wise combination is repeatedly performed until all the $\mathrm{CF}$ layers are combined to generate the landslide susceptibility.

\subsection{Index of entropy model}

Index of entropy model, based on the principle of bivariate analysis, was used for evaluating the landslide susceptibility in this study. This approach allows calculation of the weight for each input variable. In this model, the weighing process is based on the methodology proposed by Vlcko et al. (1980). The weight value for each parameter taken separately is expressed as an entropy index. In the present study, the weight parameter was obtained from the defined level of entropy representing the extent that various factors influence the development of a landslide. The information coefficient $W_{j}$ representing the weight value for the parameter as a whole was calculated using the following equations (Constantin et al. 2011; Devkota et al. 2013; Jaafari et al. 2014; Youssef et al. 2014a, b):

$$
\begin{gathered}
P_{i j}=\frac{b}{a} \\
\left(P_{i j}\right)=\frac{P_{i j}}{\sum_{j=1}^{S_{j}} P_{i j}}, \\
H_{j}=-\sum_{i=1}^{S_{j}}\left(P_{i j}\right) \log _{2}\left(P_{i j}\right), \quad j=1,2, \ldots, n, \\
H_{j \max }=\log _{2} S_{j}, \quad S_{j} \text { is the number of classes, } \\
I_{j}=\frac{H_{j \max }-H_{j}}{H_{j \max }}, \quad I=(0,1), \quad j=1, \ldots, n, \\
W_{j}=I_{j} \times P_{j},
\end{gathered}
$$

where $a$ and $b$ are the domain and landslide percentages, respectively, $\left(P_{i j}\right)$ is the probability density, $H_{j}$ and $H_{j \max }$ represent entropy values, $I_{j}$ is the information coefficient and $W_{j}$ represents the resultant weight value for the parameter as a whole. The final landslide susceptibility map is developed based on equation (9) using the ArcGIS 10.0 software.

$$
Y_{\mathrm{IOE}}=\sum_{i}^{n} \frac{z}{m_{i}} \times C \times W_{j}
$$

where $Y_{\mathrm{IOE}}$ is the sum of all the classes; $i$ is the number of particular parametric map $(1,2, \ldots, n)$; $z$ is the number of classes within parametric map 
with the greatest number of classes; $m_{i}$ is the number of classes within particular parametric map; $C$ is the value of the class after secondary classification and $W_{j}$ is the weight of a parameter (Bednarik et al. 2010; Devkota et al. 2013; Jaafari et al. 2014).

\section{Results and discussion}

\subsection{Certainty factor (CF) model}

The certainty factor rating for different classes of the causative factors show the importance of the respective classes in the slope instability. It can be observed from table 2 that the slope angle class $14^{\circ}-21^{\circ}$ has the highest value of CF (0.14) and the lowest value of $\mathrm{CF}(-1.00)$ is for slope class $28^{\circ}-38^{\circ}$. From this, it is clear that the landslide occurrence increases by the increase in slope gradient up to a certain extent, and then, it decreases (Kanungo et al. 2011). Few landslides occur on a very gentle slope and the landslide occurrence decreases as the slope becomes higher than $28^{\circ}$. A positive correlation between landslide occurrence and slope was also reported by Sun (2009). Within the slope aspect categories, the $\mathrm{CF}$ value is positive for north-facing, east-facing, southwest-facing and northwest-facing, with the maximum value $(0.40)$ at north-facing followed by east-facing (0.22) slope. The west-facing slopes are less prone to landslides as they have negative $\mathrm{CF}$ value. The $\mathrm{CF}$ values of general curvature show that the $\mathrm{CF}$ value is positive $(0.21)$ only on class $<-0.05$, indicating a high probability of landslide occurrence in this area. In the case of plan curvature, few landslides occur on $>0.05$ class. In the study area, class $>0.05$ of profile curvature has higher $\mathrm{CF}$ value (0.3), this means that the landslide probability is higher in this class. The relationship between landslide occurrence and altitude reflects that the elevations between 720 and $850 \mathrm{~m}$, and 850 and $1000 \mathrm{~m}$ have positive $\mathrm{CF}$ value (0.71 and 0.46$)$, indicating that the probability of occurrence of landslide in these altitudes is high. Meanwhile, altitude $>1300 \mathrm{~m}$ has a low $\mathrm{CF}$ value $(-0.88)$. The reason is mainly that the higher topographical elevation is formed by the lithological units resistant to landslide. In case of distance to faults, the closer the fault, the greater is the landslide probability. At a distance of $<1000 \mathrm{~m}$, the $\mathrm{CF}$ value is 0.31 , showing a high probability of a landslide. The $\mathrm{CF}$ value is lower than zero at a distance $>8000 \mathrm{~m}$ and this indicates a low probability. In the case of relationship between landslide occurrence and distance to rivers, as the distance from a drainage increases, the landslide probability generally decreases. At a distance of about $<200 \mathrm{~m}$, the $\mathrm{CF}$ value is positive $(0.48)$, indicating a high probability of landslide occurrence, and at distances about $>200 \mathrm{~m}$, the $\mathrm{CF}$ value was $<0$, indicating a low probability. This can be attributed to the fact that terrain modification caused by gully erosion and undercutting may influence the initiation of landslides. For distance from roads, a positive association with landslides is obtained for classes $<1$ and $2-3 \mathrm{~km}$ and the areas with more than $4 \mathrm{~km}$ distances from roads have low correlations with landslide occurrence in this study. A similar trend was also reported by Youssef et al. (2014a). The relation between STI landslide probabilities showed that $>15$ class has the highest value of CF (0.33), and for SPI, the class of $>40$ shows a high CF value (0.30). Similarly, for TWI, the highest $\mathrm{CF}$ value (0.41) was obtained for the interval of 10-13. In the study area, landslides were commonly observed on and close to relatively flat valley bottoms with a huge contributing area, where TWI, SPI, and STI expose higher values. A similar pattern was also observed by Jaafari et al. (2014). Geomorphology yields terrain information, which is a vital pace in learning the process of landslide initiation (Kannan et al. 2013). It is noticed that loess tableland areas have the highest influence in triggering landslides. For the lithology, it can be seen that the lithology class 5 has highest $\mathrm{CF}$ values (0.82). This indicates that lithological unit of the glutenite, sandstone and siltstone has the highest influence in triggering landslides. For the rainfall, the results show that the $\mathrm{CF}$ values in class of $650-700,>750 \mathrm{~mm} /$ year are very high (0.51) than that of the other three classes. The final result of certainty factor (CF) model is a landslide susceptibility index (LSI) map, in which the LSI values vary from -8.27 to 5.66 .

\subsection{Index of entropy (IOE) model}

To produce the landslide susceptibility map using the IOE models, every parameter map was crossed with the landslide inventory map using the ArcGIS 10.0 software, and the density $\left(P_{i j}\right)$ of the landslide occurrence in each class is calculated. The resultant weights for each thematic map for the IOE model are given in table 2 . From the $W_{j}$ value, it is seen that the altitude has the highest impact in the landslide susceptibility, followed by lithology, rainfall, and geomorphology, while others are less significant in the landslide susceptibility of the region. From the result $\left(P_{i j}\right)$, it is seen that slope interval of $14^{\circ}-21^{\circ}$ is highly prone to landslide followed by the slope class $21^{\circ}-28^{\circ}$. In the case of aspect, north-facing slopes followed by northwest-facing, east-facing, northeast-facing, and southwest-facing slopes are susceptible to landsliding. In the case of general curvature, most landslides occurred $<-0.05$. In terms of plan curvature and profile curvature, most of the existing landslides are distributed between the $<-0.05$ and 
$-0.05-0.05$ classes, and $>0.05$ class, respectively. The $P_{i j}$ value for altitude clearly showed that ranges $720-850 \mathrm{~m}$, and $850-1000 \mathrm{~m}$ have the most effect on the occurrence of landslides with high values of 0.59 and 0.32 , respectively. The other classes have low values. In the case of distance to faults, $<2000 \mathrm{~m}$ range has the highest $P_{i j}$ value (0.34) followed by 4000-6000 $\mathrm{m}(0.23), 2000-4000$ $\mathrm{m}(0.20), 6000-8000 \mathrm{~m}(0.20)$, and $>8000 \mathrm{~m}(0.04)$. The distance to rivers shows that the $P_{i j}$ value decreases as the distance to river increases. From this, it is clear that the bank erosion is one of the main triggering factors. Assessment of distance to roads showed that distance of 0-1000 and
2000-3000 m has high correlation with landslide occurrence. Most of the landslides are located at $>15$ class for STI, as the values of $P_{i j}$ is highest (0.39) here. Relation between SPI, and TWI and landslide probability showed that $>40$ and 10-13 classes have highest value of $P_{i j}$, respectively. The $P_{i j}$ value for geomorphology showed that loess tableland areas have the most effect on the occurrence of landslides with high value of 0.43 . In the case of the relationship between landslide occurrence and lithology, the value of $P_{i j}$ was higher in glutenite, sandstone and siltstone. In rainfall, the highest $P_{i j}$ value (0.34) was located in the rainfall classes of $650-700$ and $>750 \mathrm{~mm} /$ year. The

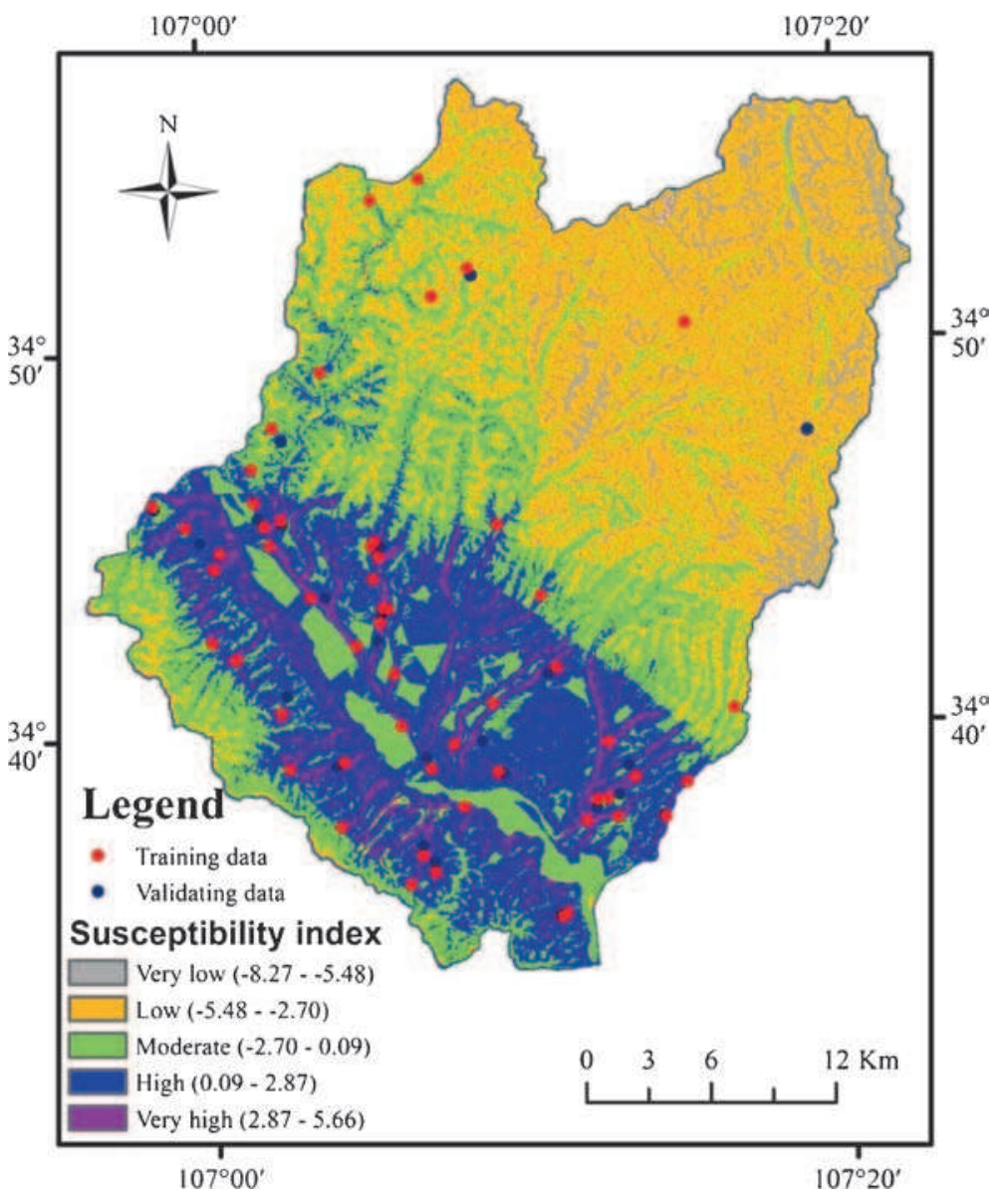

Figure 3. Landslide susceptibility map derived from the CF model.

Table 3. Comparison of predicted landslide hazard zones and observed landslides.

\begin{tabular}{lcccc}
\hline \multirow{2}{*}{$\begin{array}{l}\text { Landslide } \\
\text { susceptible zones }\end{array}$} & $\begin{array}{c}\text { Area } \\
(\%)\end{array}$ & $\begin{array}{c}\text { Landslide } \\
(\%)\end{array}$ & & \multicolumn{2}{c}{ Area } & $\begin{array}{c}\text { Landslide } \\
(\%)\end{array}$ \\
\hline Very high & 14.19 & 37.04 & 5.18 & 16.05 \\
High & 19.52 & 41.98 & 13.57 & 46.91 \\
Moderate & 20.49 & 11.11 & 14.59 & 20.98 \\
Low & 27.4 & 6.17 & 17.51 & 4.94 \\
Very low & 18.4 & 3.70 & 49.15 & 11.11 \\
\hline
\end{tabular}


findings based on entropy approach show that altitude, lithology, and rainfall are the most important factors which explain better the landslide occurrence and distribution in the study area. It should be noted that the landslide contributing factors may vary from region to region, such that the rating scheme followed in this study area may not be suitable anywhere else (Bijukchhen et al. 2013). The final result of index of entropy (IOE) model is an LSI map, in which the LSI values vary from 0.50 to 5.42 .

\subsection{Landslide susceptibility maps}

For visual interpretation of LSI maps, the data need to be classified into categorical susceptibility classes (Jaafari et al. 2014). In this study, using the natural breaks method in ArcGIS 10.0, the landslide susceptibility map generated with the certainty factor model was reclassified into five classes: very low, low, moderate, high, and very high (figure 3 ). From the output of analysis carried out using the ArcGIS 10.0 (table 3), it was found that $18.4 \%$ of the study area was placed in the group with very low susceptibility. Low, moderate and high susceptibility landslide classes comprised of 27.40, 20.49, and $19.52 \%$ of the area, respectively. In all, $14.19 \%$ of the region was placed in the class with very high landslide susceptibility. It can be observed from table 3 that 3.70 and $6.17 \%$ of the total landslides fall in the very low and low susceptibility zones respectively. Moderate, high, and very high susceptible zones represent $11.11,4.98$, and $37.04 \%$ of the landslides, respectively. In landslide susceptibility map produced from index of entropy model (figure 4), the very low susceptible zone covers $49.15 \%$ of the total study area, whereas low, moderate, high, and very high susceptible zones cover 17.51, 14.59, 13.57 and $5.18 \%$ of the total area, respectively. Meanwhile, the results show that the percentages of the total landslides in very low, low, moderate, high, and very high susceptibility classes are $11.11,4.94,20.98,46.91$, and $16.05 \%$, respectively (table 3).

\subsection{Validation of the landslide susceptibility maps}

Validation of predictive models is an essential requirement to check the accuracy of the landslide susceptibility map produced (Gorsevski et al. 2000; Chung and Fabbri 2003). The validity of the landslide susceptibility maps can be graphically

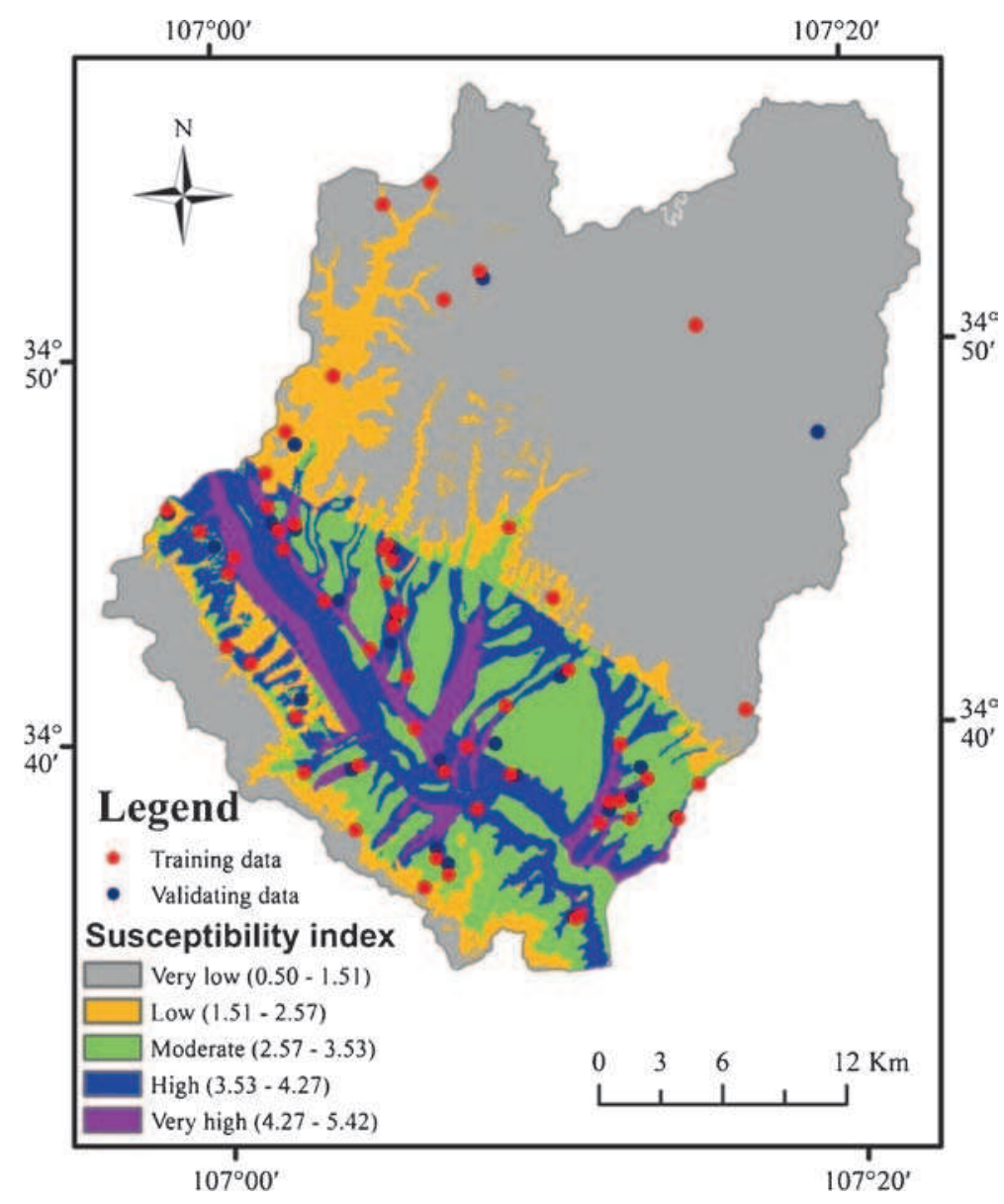

Figure 4. Landslide susceptibility map derived from the IOE model. 

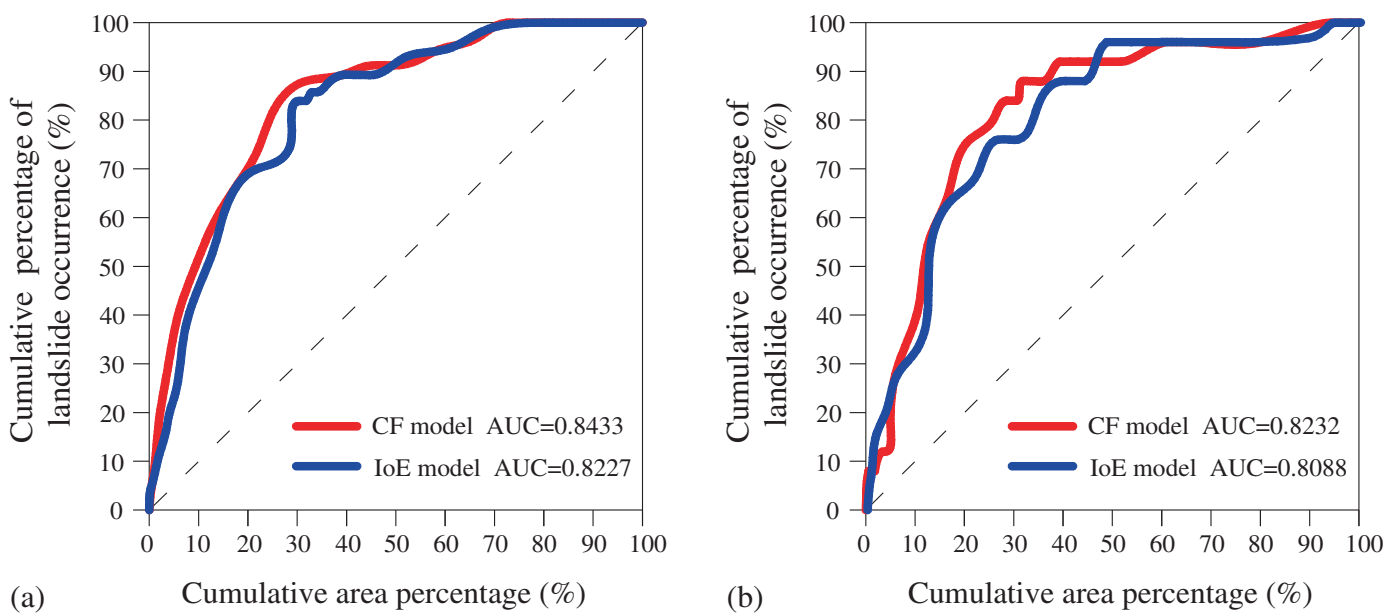

Figure 5. AUC representing quality model (a) success rate curve and (b) prediction rate curve.

ascertained with the area under curve (AUC) method (Chung and Fabbri 2003; Van Westen et al. 2003; Intarawichian and Dasananda 2011; Kayastha et al. 2013). This method works by creating specific rate curve which explains percentage of known landslides that fall into each defined level of susceptibility rank and displays as the cumulative frequency diagram (Intarawichian and Dasananda 2011). Chung and Fabbri (2003) distinguished between success- and prediction-rate curves. A success rate curve is based on a comparison of the susceptibility map with the landslides used in modelling (i.e., the training set). This is considered as a degree of fit measure (Chung and Fabbri 2003; Pradhan and Kim 2014). Apart from the success rate curve, the prediction rate curve is a good indicator of the predictive power of the susceptibility map. The prediction rate curve can be created by the validation landslide inventory (Pradhan and Kim 2014). In rate curve, the $y$ axis is normally considered as the cumulative percentage of observed landslide occurrences in different susceptibility classes and the $x$ axis corresponds to the cumulative percentage of the area of the susceptibility classes. Total area under a rate curve (AUC) can be used to determine prediction accuracy of the susceptibility map qualitatively in which larger area means higher accuracy achieved (Lee 2005; Mathew et al. 2009; Intarawichian and Dasananda 2011; Pourghasemi et al. 2013b). In this study, at first, the total landslides observed in the study area were split into two parts, 56 (70\%) landslides were randomly selected from the total 81 landslides as the training data and the remaining $25(30 \%)$ landslides were kept for validation propose. Then the rate curves were obtained by comparing the landslide training data and validation data with the susceptibility maps and the areas under the curve were calculated.

The success rate curves of $\mathrm{CF}$ and IOE models shown in figure $5(\mathrm{a})$, indicate that the first $10 \%$ of the area of the susceptibility classes can explain about $52 \%, 48 \%$ of all used landslides (out of 56 events), respectively. The first about $72 \%$ for $\mathrm{CF}$ and IOE models can accommodate all known landslides. Similarly, the prediction rate curves (figure $5 \mathrm{~b}$ ) indicate that the first $10 \%$ of the area of the susceptibility classes can explain about $37 \%$ and $32 \%$ of all used landslides (out of 25 events), respectively. The first, about $93 \%$ for CF and IOE models can accommodate all known landslides. From calculation of the AUC for CF and IOE models, it was found that AUC for the success rate curves are 0.8433 and 0.8227 , respectively. Namely, the training accuracy of the susceptibility maps is $84.33 \%$ and $82.27 \%$, respectively. The areas of prediction rate curves are 0.8232 and 0.8088 , which means that the overall prediction rates are $82.32 \%$ and $80.88 \%$ for the $\mathrm{CF}$ and IOE models, respectively. These results show that the CF and IOE models are successful estimators, and the two models employed in this study have reasonably good accuracy in predicting the landslide susceptibility of the study area. The map produced by CF model exhibited the better result for landslide susceptibility mapping in the study area.

\section{Conclusions}

In this study, both certainty factor and index of entropy models to estimate areas susceptible to landslides for the Qianyang County of Baoji city, China, using GIS has been presented. The relationship between a landslide occurrence and the identified 15 causative factors such as slope angle, slope aspect, general curvature, plan curvature, profile curvature, altitude, distance to faults, distance to rivers, distance to roads, STI, SPI, TWI, geomorphology, lithology, and rainfall was evaluated using $\mathrm{CF}$ and IOE methods. The selection of the 15 conditioning landslide factors, based on consideration of relevance, availability, and scale of data that was 
available for the study area, is relative and subjective, and can be improved in future research. Before susceptibility analysis, a total of 81 landslides observed in the area were separated into two groups, 56 (70\%) landslides were randomly selected for generating a model and the remaining $25(30 \%)$ were used for validation proposes. The susceptibility maps produced by $\mathrm{CF}$ and IOE models were divided into five different susceptibility classes such as very low, low, moderate, high, and very high. The area under the rate curve quantitatively indicates the performance of the susceptibility maps. The results show that the $\mathrm{CF}$ model with a success rate of $84.33 \%$ and predictive accuracy of $82.32 \%$ performs better than IOE (success rate, 82.27\%; predictive accuracy, $80.88 \%$ ) models. Overall, both models showed almost similar results and were reasonable models for the landslide susceptibility mapping of the study area. In addition, it should be noted that both the models were developed on some basic assumptions such as topography, geology, and stream, etc. If data on factors causing the landslides, such as extreme rainfall, earthquake shaking, exist, then a more accurate analysis could be done.

The output results of the present study can help the decision makers, managers, urban planners, engineers, and land-use developers to manage slopes and choose susceptible locations to accomplish development in wild land as well as urban areas. Also, it is worth mentioning that similar method can be used elsewhere where the same geological and topographical feature prevails.

\section{Acknowledgements}

The authors would like to express their gratitude to everyone who provided assistance for the present study. The study is jointly supported by the State Key Program of National Natural Science of China (Grant No. 41430643) and National Program on Key Basic Research Project (Grant No. 2015CB251601).

\section{References}

Akgun A 2012 A comparison of landslide susceptibility maps produced by logistic regression, multi-criteria decision, and likelihood ratio methods: A case study at İzmir, Turkey; Landslides 9 93-106.

Akgun A and Turk N 2010 Landslide susceptibility mapping for Ayvalik (western Turkey) 379 and its vicinity by multicriteria decision analysis; Environ. Earth Sci. 61(3) 595-611.

Akgun A, Dag S and Bulut F 2008 Landslide susceptibility mapping for a landslide-prone area (Findikli, NE of Turkey) by likelihood-frequency ratio and weighted linear combination models; Environ. Geol. 54(6) 1127-1143.

Akgun A, Kincal C and Pradhan B 2012 Application of remote sensing data and GIS for landslide risk assessment as an environmental threat to Izmir city (West Turkey); Environ. Monit. Assess. 184 5453-5470.
Bednarik M, Magulova B, Matys M and Marschalko M 2010 Landslide susceptibility assessment of the KralovanyLiptovsky Mikulas railway case study; Phys. Chem. Earth Parts $A / B / C$ 35(3-5) 162-171.

Bijukchhen S M, Kayastha P and Dhital M R 2013 A comparative evaluation of heuristic and bivariate statistical modelling for landslide susceptibility mappings in Ghurmi-Dhad Khola, east Nepal; Arabian J. Geosci. 6(8) 2727-2743.

Chauhan S, Sharma M, Arora M and Gupta N 2010 Landslide susceptibility zonation through ratings derived from artificial neural network; Intl. J. Appl. Earth Observ. Geoinf. 12 340-350.

C.H. of China Meteorological Administration(CMA) (2014) http://cdc.cma.gov.cn/cdc_en/home.dd.

Choi J, Oh H J, Lee H J, Lee C and Lee S 2012 Combining landslide susceptibility maps obtained from frequency ratio, logistic regression, and artificial neural network models using ASTER images and GIS; Eng. Geol. 124 12-23.

Chung C J F and Fabbri A G 2003 Validation of spatial prediction models for landslide hazard mapping; Nat. Hazards 30(3) 451-472.

Conforti M, Aucelli P P, Robustelli G and Scarciglia F 2011 Geomorphology and GIS analysis for mapping gully erosion susceptibility in the Turbolo stream catchment (northern Calabria, Italy); Nat. Hazards 56(3) 881-898.

Constantin M, Bednarik M, Jurchescu M C and Vlaicu M 2011 Landslide susceptibility assessment using the bivariate statistical analysis and the index of entropy in the Sibiciu Basin (Romania); Environ. Earth Sci. 63(2) 397-406.

Dai F C and Lee C F 2002 Landslide characteristics and slope instability modeling using GIS, Lantau Island, Hong Kong; Geomorphology 42(3) 213-228.

Demir G, Aytekin M, Akgün A, İkizler S B and Tatar O 2013 A comparison of landslide susceptibility mapping of the eastern part of the North Anatolian Fault Zone (Turkey) by likelihood-frequency ratio and analytic hierarchy process methods; Nat. Hazards 65(3) 1481-1506.

Devkota K C, Regmi A D, Pourghasemi H R, Yoshida K, Pradhan B, Ryu I C, Dhital M R and Althuwaynee O F 2013 Landslide susceptibility mapping using certainty factor, index of entropy and logistic regression models in GIS and their comparison at Mugling-Narayanghat road section in Nepal Himalaya; Nat. Hazards 65 135-165.

Dou J, Oguchi T, Hayakawa Y S, Uchiyama S, Saito H and Paudel U 2014 GIS-based landslide susceptibility mapping using a certainty factor model and its validation in the Chuetsu area, central Japan; In: Landslide Science for a Safer Geoenvironment (Springer International Publishing), pp. 419-424.

Dragićević S, Lai T and Balram S 2015 GIS-based multicriteria evaluation with multiscale analysis to characterize urban landslide susceptibility in data-scarce environments; Habitat Intl. 45 114-125.

Gorsevski P V, Gessler P and Foltz R B 2000 Spatial prediction of landslide hazard using discriminant analysis and GIS; In: GIS in the Rockies 2000 Conference and Workshop.

Gorsevski P V, Donevska K R, Mitrovski C D and Frizado J P 2012 Integrating multi-criteria evaluation techniques with geographic information systems for landfill site selection: A case study using ordered weighted average; Waste Management 32(2) 287-296.

Grozavu A, Plescan S, Patriche C V, Margarint M C and Rosca B 2013 Landslide susceptibility assessment: GIS application to a complex mountainous environment; The Carpathians: Integrating Nature and Society Towards Sustainability; Environ. Sci. Engg., pp. 31-44. 
Guettouche M S 2013 Modeling and risk assessment of landslides using fuzzy logic. Application on the slopes of the Algerian Tell (Algeria); Arab J. Geosci. 6 3163-3173.

Heckeman 1986 Probabilistic interpretation of MYCIN's certainty factors; In: Uncertainty in artificial intelligence (eds) Kanal L N and Lemmer J F (New York: Elsevier), pp. 298-311.

Ilia I, Koumantakis I, Rozos D, Koukis G and Tsangaratos P 2015 A geographical information system (GIS) based probabilistic certainty factor approach in assessing landslide susceptibility: The case study of Kimi, Euboea, Greece; In: Engineering Geology for Society and Territory, Vol. 2, Springer International Publishing, pp. 1199-1204.

Intarawichian N and Dasananda S 2011 Frequency ratio model based landslide susceptibility mapping in lower Mae Chaem watershed, Northern Thailand; Environ. Earth Sci. 64(8) 2271-2285.

Jaafari A, Najafi A, Pourghasemi H R, Rezaeian J and Sattarian A 2014 GIS-based frequency ratio and index of entropy models for landslide susceptibility assessment in the Caspian forest, northern Iran; Int. J. Environ. Sci. Tech. 11(4) 909-926.

Kannan M, Saranathan E and Anabalagan R 2013 Landslide vulnerability mapping using frequency ratio model: A geospatial approach in Bodi-Bodimettu Ghat section, Theni district, Tamil Nadu, India; Arabian J. Geosci. 6(8) 2901-2913.

Kanungo D P, Sarkar S and Sharma S 2011 Combining neural network with fuzzy, certainty factor and likelihood ratio concepts for spatial prediction of landslides; Nat. Hazards 59(3) 1491-1512.

Kayastha P, Dhital M R and De Smedt F 2013 Evaluation of the consistency of landslide susceptibility mapping: A case study from the Kankai watershed in east Nepal; Landslides 10(6) 785-799.

Kritikos T and Davies T 2014 Assessment of rainfallgenerated shallow landslide/debris-flow susceptibility and runout using a GIS-based approach: Application to western Southern Alps of New Zealand; Landslides, doi: 10.1007/s10346-014-0533-6.

Lee S 2005 Application and cross-validation of spatial logistic multiple regression for landslide susceptibility analysis; Geosci. J. 9(1) 63-71.

Lee S and Min K 2001 Statistical analyses of landslide susceptibility at Yongin, Korea; Environ. Geol. 40 1095-1113.

Lee S and Pradhan B 2007 Landslide hazard mapping at Selangor, Malaysia using frequency ratio and logistic regression models; Landslides 4(1) 33-41.

Liu C, Li W, Wu H, Lu P, Sang K, Sun W and Li R 2013 Susceptibility evaluation and mapping of China's landslides based on multi-source data; Nat. Hazards 69(3) 1477-1495.

Liu M, Chen X and Yang S 2014 Collapse landslide and mudslide hazard zonation; In: Landslide science for a safer geoenvironment (Springer International Publishing), pp. $457-462$.

Mathew J, Jha V K and Rawat G S 2009 Landslide susceptibility zonation mapping and its validation in part of Garhwal Lesser Himalaya, India, using binary logistic regression analysis and receiver operating characteristic curve method; Landslides 6(1) 17-26.

Mihaela C, Martin B, Marta C J and Marius V 2011 Landslide susceptibility assessment using the bivariate statistical analysis and the index of entropy in the Sibiciu Basin (Romania); Environ. Earth Sci. 63 397-406.

Moore I D, O'loughlin E M and Burch G J 1988 A contourbased topographic model for hydrological and ecological applications; Earth Surface Processes and Landforms 13(4) 305-320.
Nefeslioglu H A, Duman T Y and Durmaz S 2008 Landslide susceptibility mapping for a part of tectonic Kelkit valley (Eastern Black Sea region of Turkey); Geomorphology 94(3) 401-418.

Nefeslioglu H A, Sezer E, Gokceoglu C, Bozkir A S and Duman T Y 2010 Assessment of landslide susceptibility by decision trees in the metropolitan area of Istanbul, Turkey; Mathematical Problems in Engineering, Article ID 901095, 15p.

Neuhäuser B, Damm B and Terhorst B 2012 GIS-based assessment of landslide susceptibility on the base of the weights-of-evidence model; Landslides 9(4) 511-528.

Oh H J, Lee S, Chotikasathien W, Kim C H and Kwon J H 2009 Predictive landslide susceptibility mapping using spatial information in the Pechabun area of Thailand; Environ. Geol. 57(3) 641-651.

Ozdemir A and Altural T 2013 A comparative study of frequency ratio, weights of evidence and logistic regression methods for landslide susceptibility mapping: Sultan Mountains, SW Turkey; J. Asian Earth Sci. 64 180-197.

Pareek N, Sharma M L and Arora M K 2010 Impact of seismic factors on landslide susceptibility zonation: A case study in part of Indian Himalayas; Landslides 7 (2) 191-201.

Park S, Choi C, Kim B and Kim J 2013 Landslide susceptibility mapping using frequency ratio, analytic hierarchy process, logistic regression, and artificial neural network methods at the Inje area, Korea; Environ. Earth Sci. 68 1443-1464.

Pradhan B 2010a Remote sensing and GIS-based landslide hazard analysis and cross-validation using multivariate logistic regression model on three test areas in Malaysia; Adv. Space Res. 45 1244-1256.

Pradhan B 2010b Landslide susceptibility mapping of a catchment area using frequency ratio, fuzzy logic and multivariate logistic regression approaches; J. Indian Soc. Remote Sens. 38(2) 301-320.

Pradhan B 2013 A comparative study on the predictive ability of the decision tree, support vector machine and neurofuzzy models in landslide susceptibility mapping using GIS; Comput. Geosci. 51 350-365.

Pradhan B and Buchroithner M F 2010 Comparison and validation of landslide susceptibility maps using an artificial neural network model for three test areas in Malaysia; Environ. Eng. Geosci. 16(2) 107-126.

Pradhan A M S and Kim Y T 2014 Relative effect method of landslide susceptibility zonation in weathered granite soil: A case study in Deokjeok-ri Creek, South Korea; Nat. Hazards 72(2) 1189-1217.

Pradhan B and Lee S 2010 Landslide susceptibility assessment and factor effect analysis: Back-propagation artificial neural networks and their comparison with frequency ratio and bivariate logistic regression modeling; Environ. Modeling Software 25(6) 747-759.

Pradhan B and Youssef A M 2010 Manifestation of remote sensing data and GIS on landslide hazard analysis using spatial-based statistical models; Arab. J. Geosci. 3(3) 319-326.

Pradhan B, Mansor S, Pirasteh S and Buchroithner M 2011 Landslide hazard and risk analyses at a landslide prone catchment area using statistical based geospatial model; Int. J. Remote Sens. 32(14) 4075-4087.

Pourghasemi H R, Pradhan B and Gokceoglu C 2012a Application of fuzzy logic and analytical hierarchy process (AHP) to landslide susceptibility mapping at Haraz watershed, Iran; Nat. Hazards 63 965-996.

Pourghasemi H R, Pradhan B, Gokceoglu C and Moezzi K D 2012b Landslide susceptibility mapping using a spatial multi criteria evaluation model at Haraz Watershed, 
Iran; In: Terrigenous Mass Movements, Springer-Berlin Heidelberg, pp. 23-49.

Pourghasemi H R, Mohammady M and Pradhan B 2012c Landslide susceptibility mapping using index of entropy and conditional probability models in GIS: Safarood Basin, Iran; Catena 97 71-84.

Pourghasemi H R, Moradi H R and Aghda S F 2013a Landslide susceptibility mapping by binary logistic regression, analytical hierarchy process, and statistical index models and assessment of their performances; Nat. Hazards 69(1) 749-779.

Pourghasemi H R, Jirandeh A G, Pradhan B, Xu C and Gokceoglu C 2013b Landslide susceptibility mapping using support vector machine and GIS at the Golestan Province, Iran; J. Earth Syst. Sci. 122(2) 349-369.

Pourghasemi H R, Pradhan B, Gokceoglu C, Mohammadi M and Moradi H R 2013c Application of weights-of-evidence and certainty factor models and their comparison in landslide susceptibility mapping at Haraz Watershed, Iran; Arabian J. Geosci. 6(7) 2351-2365.

Pouydal C P, Chang C, Oh H J and Lee S 2010 Landslide susceptibility maps comparing frequency ratio and artificial neural networks: A case study from the Nepal Himalaya; Environ. Earth Sci. 61 1049-1064.

Regmi A D, Devkota K C, Yoshida K, Pradhan B, Pourghasemi H R, Kumamoto T and Akgun A 2014 Application of frequency ratio, statistical index, and weights-of-evidence models and their comparison in landslide susceptibility mapping in Central Nepal Himalaya; Arab J. Geosci. 7(2) 725-742.

Saadatkhah N, Kassim A and Lee L M 2014 Susceptibility assessment of shallow landslides in Hulu Kelang area, Kuala Lumpur, Malaysia using analytical hierarchy process and frequency ratio; Geotech. Geol. Engg. 33 43-57.

Saha A K, Gupta R P, Sarkar I, Arora M K and Csaplovics E 2005 An approach for GIS-based statistical landslide susceptibility zonation with a case study in the Himalayas; Landslides 2 61-69.

Saponaro A, Pilz M, Wieland M, Bindi D, Moldobekov B and Parolai S 2014 Landslide susceptibility analysis in data-scarce regions: The case of Kyrgyzstan; Bull. Engg. Geol. Environ., doi: 10.1007/s10064-014-0709-2.

Sezer E A, Pradhan B and Gokceoglu C 2011 Manifestation of an adaptive neuro-fuzzy model on landslide susceptibility mapping: Klang valley, Malaysia; Exp. Syst. Appl. 38 8208-8219.

Sharma L P, Patel Nilanchal, Ghose M K and Debnath P 2013 Synergistic application of fuzzy logic and geoinformatics for landslide vulnerability zonation - a case study in Sikkim Himalayas, India; Appl. Geomat. 5 271-284.

Shortliffe E H and Buchanan B G 1975 A model of inexact reasoning in medicine; Math. Biosci. 23(3) 351-379.

Solaimani K, Mousav S Z and Kavian A 2013 Landslide susceptibility mapping based on frequency ratio and logistic regression models; Arabian J. Geosci. 6(7) 2557-2569.

Sujatha E R, Rajamanickam G V and Kumaravel P 2012 Landslide susceptibility analysis using probabilistic certainty factor approach: A case study on Tevankarai stream watershed, India; J. Earth Syst. Sci. 121(5) 1337-1350.

Sujatha E R, Kumaravel $\mathrm{P}$ and Rajamanickam G V 2014 Assessing landslide susceptibility using Bayesian probability-based weight of evidence model; Bull. Engg. Geol. Environ. 73(1) 147-161.
Sun W F 2009 Study of landslide hazard assessment on typical loess area in Qianhe valley, Qianyang County (Ph.D dissertation: Chinese Academy of Geological Science, Beijing).

Vahidnia M H, Alesheikh A A, Alimohammadi A and Hosseinali F 2010 A GIS-based neuro-fuzzy procedure for integrating knowledge and data in landslide susceptibility mapping; Comput. Geosci. 36(9) 1101-1114.

Van Westen C J, Rengers N and Soeters R 2003 Use of geomorphological information in indirect landslide susceptibility assessment; Nat. Hazards 30(3) 399-419.

Van Westen C J, Van Asch T W and Soeters R 2006 Landslide hazard and risk zonation - why is it still so difficult? Bull. Engg. Geol. Environ. 65(2) 167-184.

Vijith H and Madhu G 2008 Estimating potential landslide sites of an upland sub-watershed in Western Ghats of Kerala (India) through frequency ratio and GIS; Environ. Geol. 55(7) 1397-1405.

Vlcko J, Wagner P and Rychlikova Z 1980 Evaluation of regional slope stability; Mineralia Slovaca 12(3) 275-283.

Wang J M 2008 Research on the Stability of Tashan Loess Landslide of Qianyang County (Ph.D dissertation: China University of Geosciences, Beijing).

Yalcin A and Bulut F 2007 Landslide susceptibility mapping using GIS and digital photogrammetric techniques: A case study from Ardesen (NE-Turkey); Nat. Hazards 41(1) 201-226.

Yalcin A, Reis S, Cagdasoglu A and Yomralioglu T 2011 A GIS-based comparative study of frequency ratio, analytical hierarchy process, bivariate statistics and logistics regression methods for landslide susceptibility mapping in Trabzon, NE Turkey; Catena 85 274287.

Yang C 2009 The research on the distribution characteristics and the layout optimization of the land for mountainous rural settlements (Ph.D dissertation, Xi'an, Northwest University).

Yilmaz I 2010 Comparison of landslide susceptibility mapping methodologies for Koyulhisar, Turkey: Conditional probability, logistic regression, artificial neural networks, and support vector machine; Environ. Earth Sci. 61 821-836.

Yilmaz I and Keskin I 2009 GIS based statistical and physical approaches to landslide susceptibility mapping (Sebinkarahisar, Turkey); Bull. Engg. Geol. Environ. 68(4) 459-471.

Youssef A M, Pradhan B, Gaber A F D and Buchroithner M F 2009 Geomorphological hazard analysis along the Egyptian Red Sea coast between Safaga and Quseir; Nat. Hazard Earth Syst. 9 751-766.

Youssef A M, Pradhan B, Sabtan A A and El-Harbi H M 2012 Coupling of remote sensing data aided with field investigations for geological hazards assessment in Jazan area, Kingdom of Saudi Arabia; Environ. Earth Sci. 65(1) 119-130.

Youssef A M, Al-Kathery M and Pradhan B 2014a Landslide susceptibility mapping at Al-Hasher area, Jizan (Saudi Arabia) using GIS-based frequency ratio and index of entropy models; Geosci. J. 19(1) 113-134.

Youssef A M, Pradhan B, Jebur M N and El-Harbi H M 2014b Landslide susceptibility mapping using ensemble bivariate and multivariate statistical models in Fayfa area, Saudi Arabia; Environ. Earth Sci. 73(7) 37453761 . 